This item was submitted to Loughborough's Research Repository by the author.

Items in Figshare are protected by copyright, with all rights reserved, unless otherwise indicated.

\title{
From media systems to media cultures
}

PLEASE CITE THE PUBLISHED VERSION

https://www.icahdq.org/page/PastFuture

\section{VERSION}

AM (Accepted Manuscript)

\section{PUBLISHER STATEMENT}

This work is made available according to the conditions of the Creative Commons Attribution-NonCommercialNoDerivatives 4.0 International (CC BY-NC-ND 4.0) licence. Full details of this licence are available at: https://creativecommons.org/licenses/by-nc-nd/4.0/

LICENCE

CC BY-NC-ND 4.0

REPOSITORY RECORD

Mihelj, Sabina. 2019. “From Media Systems to Media Cultures”. figshare. https://hdl.handle.net/2134/37150. 


\title{
From Media Systems to Media Cultures: Reorienting Comparative Media Research ${ }^{1}$
}

\begin{abstract}
The comparative study of media systems and their relationships with political systems has received a substantial amount of attention in recent years, and made significant strides in understanding the diversity of mass communication around the world, along with its causes. Yet, while this systemic approach is important, it offers it offers only a partial insight into diversity of global media landscapes and, more generally, into the social implications of mass communication. To gain a fuller grasp of these implications, we need to start from the premise that socially significant communication extends well beyond the traditional domains of politics, and encompasses the mediation of basic cultural ideals and narratives, as well as the structuring of everyday practices and routines. These include the perceptions of private and public life, the understanding of the nation and its position in the world, the modes of organizing daily routines and everyday spaces, the historical events remembered and celebrated on a mass scale, and much more. To investigate these dimensions, this paper develops a conceptual and analytical framework that conceives of media cultures as patterns of ideas and practices that enable mass mediated meaning formation, and that have distinct spatial and temporal characteristics. These media cultures can vary on a number of dimensions, from the extent to which they seek to serve public or private goals, the degree to which they are open to transnational exchanges, to their modes of engaging with the past, present and future. This framework can be applied to different media and cultural forms, and in diverse political and cultural contexts. By way of illustration, the paper outlines how the framework can be used for the comparative study of (analogue) television cultures.
\end{abstract}

KEYWORDS: Media cultures; Comparative media research; Television, Privacy, Publicness

Comparative media research has advanced considerably over the previous two decades, evolving from a marginal preoccupation to a well-stablished subfield of media and communication research. As Sonia Livingstone (2012: 415) notes, the conduct of research within a single country can no longer be taken for granted, and has to be accompanied, at the

\footnotetext{
${ }^{1}$ This paper has not been previously published nor presented. It is based in part on one of the chapters from a book manuscript that is scheduled for publication in summer/autumn 2018 (Anonymised, forthcoming 2018). The paper is based on research funded by the Leverhulme Trust, reference RPG-2013-025.
} 
very minimum, by asking whether the findings are limited to that country or part of a wider transnational trend. In the process of achieving greater recognition in the field, comparative research has also reached a considerable level of methodological and theoretical sophistication, and enlarged its substantive and geographical scope. As a result, it is now possible to identify a significant body of comparative work across all the major sub-fields of communication and media research, ranging from political communication to social interaction, and from media policy and regulation to audience reception (for an overview see Esser and Hanitzsch 2012).

Yet if we look more closely at which kinds of substantive questions have received the most attention, it is clear that existing research focuses primarily on political communication and news genres, and have little to say about entertainment and popular genres, and about cultural aspects of mediated communication more generally. These tendencies are clearly evident in what is presently the most influential study in the field, namely Hallin and Mancini's (2004) Comparing Media Systems. In this landmark book, the authors examine eighteen countries in Western Europe and Northern America, focusing on news media and regulation. Although the choice of the term "system" implies comprehensiveness, the chosen focus effectively means that what are being compared are, for the most part, political communication systems, rather than media systems in general. The authors readily acknowledge that their analysis could be expanded to encompass other cultural industries, but admit that this would "involve other literatures and require very different sets of concepts" (Hallin and Mancini 2004: 7).

Building on existing critiques of comparative media research, this paper develops a new theoretical and analytical framework for comparative work, one that seeks to shift attention from media systems to media cultures. ${ }^{2}$ The rationale for such a move is simple but farreaching: While the systemic approach is important, it offers only a partial insight into diversity of global media landscapes and, more generally, into the social effects of mass communication. To gain a fuller grasp of these effects, we need to start from the premise that socially significant communication extends well beyond the traditional domains of politics, and encompasses the mediation of basic cultural ideals and narratives, as well as the structuring of everyday practices and routines. These include the perceptions of private and public life, the understanding of the nation and its position in the world, the modes of organizing daily

\footnotetext{
2 Systemic aspects of course remain important; a comparative inquiry into media cultures cannot proceed without a parallel consideration of media systems, which constitute one of the major contextual factors that help explain why media cultures are the way they are.
} 
routines and everyday spaces, the historical events remembered and celebrated on a mass scale, and much more. If the comparative analysis of media systems enables us to understand how and why different political systems shape various forms of political communication, the comparative analysis of media cultures can help us unpack how and why different media systems help reproduce or change shared beliefs and practices.

The idea of focusing comparative efforts on cultural features is of course not a new one in media research. A significant body of existing comparative, cross-country research in the field deals with aspects of mass communication that concern culture. Particularly voluminous is the literature examining journalistic values and practices across several countries and the body of cross-country research on news, which focuses either on the general conventions and trends in news reporting, or on patterns in the coverage of particular topics such as EU affairs (e.g., Chalaby 1996; de Vreese et al. 2001; Esser 1999). Other media genres have received their share of attention too, and a sizeable comparative literature now exists on a range of forms of representation across different media platforms, including soap operas, reality television formats, and advertising (e.g., Allen 1995; Furnham and Mak 1999; Van Keulen and Krijnen 2014). Audience habits and reception have also been examined comparatively, both from the perspective of the changing media environments of selected social groups, as well as with regard to the reception of globally successful programmes such as Dallas or The Lord of the Rings (e.g., Barker and Mathijs 2008; Liebes and Katz 1990; Livingstone and Bovill 2013.

It is only very recently, however, that scholars interested in comparative approaches have begun to conceptualize these cultural aspects in a more concerted manner, and to consider the best ways of comparing them (e.g., Couldry and Hepp 2012; Hanitzsch 2007). Several useful theoretical and methodological suggestions have been put forward, but so far have neither coalesced into a shared approach, nor given rise to a firm understanding of what comparing media cultures actually involves. This paper builds on these recent efforts to develop a more fully-fledged conceptual and analytical framework for comparing media cultures. The first part develops a definition of media culture, understood as distinctive patterns of ideas and practices tied to specific forms of mass mediated communication, which shape processes of meaning-formation across instances of production, reception and use. This is followed by a discussion of selected dimensions of variation among media cultures, with a focus on (pre-digital) television. Four such dimensions are considered: publicness, privacy, temporal orientation, and secularization. The paper concludes by discussing two major 
Wordcount: 7995 (references excluded)

methodological obstacles facing comparative media culture research: the danger of methodological nationalism and the challenge of combining cross-country comparison with researching change over time.

\section{Defining Media Culture}

A closer look at recent literature on media cultures reveals that the field of comparative media culture research - if indeed it can be called a field at this point - lacks a shared understanding of what such work should focus on. In that sense, the current state of comparative media cultures research is similar to the one described by Blumler and Gurevitch (1995: 75) half a century ago in relation to comparative political communication research: "It is not merely that few political communication studies have yet been mounted with a comparative focus. More to the point, there is neither a settled view of what such studies should be concerned with, nor even a firmly crystallized set of alternative options for research between which scholars of diverse philosophic persuasions could choose from." Although the volume of existing comparative research on media cultures is significantly larger than the volume of comparative work in political communication at the time Blumler and Gurevich wrote their book, a shared sense of what such work should examine, and of the different methodological and theoretical approaches available, is still lacking.

The first question we need to address, then, is one of definition: what do we mean by media culture? Two broad approaches can be identified in the existing literature, which differ in the way they conceive of the relationship between media and culture: one sees culture as either internal to, or in large part determined by the media, while the other approaches culture as an external force that influences the media. In the first group we find studies that understand culture as shaped by a specific mode of mediated cultural transmission; in this sense, we can talk of "television culture", "news culture", "journalistic culture", "reality TV culture", "fan culture", or simply, in generic terms, "media culture". A shared trait of these studies is that they think of media culture as a complex of practices and/or ideas (meanings, discourses etc.) that is tied either to a distinct media genre, or to a distinct mass medium, or to modern mass communication media in general. For instance, Thomas Hanitzsch (2007: 369) understands "journalism culture" as "a particular set of ideas and practices by which journalists legitimate their role in society and render their work meaningful". In this sense, journalism culture is a form of culture linked to a particular media genre, namely news. Couldry and Hepp's (2012: 
253-256) discussion of media culture follows a similar logic, albeit at a more general level. They define "media culture" as "any culture whose primary resources of meaning are mediated or provided by technologies of media communication", and then go on to conceptualize such culture as "a thickening of classificatory systems and discursive formations on which the production of meaning in everyday practice draws". In this case, media culture is simply any form of mass mediated culture. A closely similar conception of media culture emerges from the work of social theorists such as Douglas Kellner (1995) and Nick Stevenson (2002, both of whom use the term to refer to culture that is transmitted through, and hence in some fundamental way shaped by, modern means of mass communication.

A very different notion of culture is found in comparative work on cross-cultural communication, where culture - often termed communication culture or cultural communication - refers to communication practices, patterns or codes that are unique to particular cultural groups (Gudykunst and Mody 2002; Kim 2012; Ting-Toomey and Chung 2012). While also conceived as a complex of practices and/or ideas, communication culture is not tied to a particular medium or genre, but to specific cultural groups, typically defined in ethnic or national terms. Even though such work can occasionally investigate the shared cultural meanings engendered by a particular medium or genre regardless of context, the main emphasis is on divergent features that arise from the production or consumption of this medium or genre among different cultural groups. To put it differently, communication cultures exist relatively independently from the mass media, are seen as rooted in cultural traditions established over time, and as in large part dependent on modes of interpersonal communication that do not necessarily require media technologies. Understanding the relationship between media and culture in this way implies that the diversity of media cultures can be explained solely or primarily with reference to cultural or civilizational differences. Such an approach runs the risk of essentializing culture, and does not offer sufficient breath for the kind of comparative analysis proposed here. This is not to say that cultural differences should be ignored; media cultures certainly differ depending on a range of cultural factors, including religious and ethno-cultural traditions. Yet, such cultural differences are not all that matters; they operate alongside political, economic, and socio-demographic factors, and hence constituted only one piece of a much larger puzzle.

The understanding of culture adopted in this paper therefore belongs to the first category: the focus is on media cultures, understood as patterns of ideas and practices tied to specific forms 
Wordcount: 7995 (references excluded)

of mass mediated communication, which shape processes of meaning-formation across instances of production, reception and use. More precisely, this paper focuses on television culture, that is, the distinct patterns of ideas and practices linked to television.

Having clarified what we mean by media culture, it is now time to consider how we can examine it empirically. Which of the many patterns of ideas or practices should we focus on in order to ensure both a measure of commonality and hence comparability, and sufficient variety and hence differentiation? One solution, particularly common in existing comparative work on media culture, involves finding a shared theme or object at the level of media texts, such as a theme or feature appearing in news coverage internationally, or a media format or programme adopted globally (e.g., Allen 1995; de Vreese et al. 2001; Esser 1999; Furnham and Mak 1999; Liebes and Katz 1990; van Keulen and Krijnen 2014). Another popular approach focuses on practices or values across different social groups involved in mass mediated communication, such as foreign correspondents, or audiences (e.g., Hannerz 2004; Livingstone and Bovill 2013). Both of these approaches have their distinct advantages, but they offer only a partial insight into the diversity of media cultures. To start with, they often result in work that fragments the process of communication into moments of production, texts and reception and use, and focuses on one of them. At the same time, the emphasis on themes and groups also tends to detract attention from the medium or form of communication itself, and the particular ways in which it shapes the whole process of meaning-making from production to reception and use.

The analytical framework developed in this paper builds on these established methods of comparing media cultures, but embeds them in an approach that also pays attention to how they interact with the inherent qualities of the medium. To paraphrase Marshall McLuhan (1994), the investigation of the messages conveyed in media "content" is complemented by the study of the medium itself as a message, and of the way it embeds itself both in the content of communication and in the particular practices and perceptions shared among producers or audiences. In practical terms this means that the analysis of television cultures should cover the televised representations of particular themes and events, the practices and preferences of audiences, and the views of television professionals and political elites, but ties them to a consideration of the specific affordances ingrained in television technology and infrastructure. 
Attempts to link different communication technologies to the characteristic features of societies and cultures using them have a long history. An early example is found in the distinction between space-biased and time-biased media developed by the Canadian political economist Harold Innis (2007, 2008). According to Innis, communication technologies dominant before the rise of print, such as parchment or clay tablets, were time-biased: they were hardy and durable and hence easily weathered the passage of time, but they also proved difficult to replicate and were therefore resistant to dissemination over space. As such, they were conducive to forms of governance that operated on spatially delimited territories and were reliant on the reproduction of tradition over time, and were typically associated with societies and cultures that were relatively conservative and stable. In contrast, modern communication technologies such as print, radio and television are space-biased: they are ephemeral and perishable and hence less well suited for the transmission of messages over time, but at the same time, they are also light and easily transportable or replicable, and therefore have the capacity to reach large audiences over long distances. As such, they tend to facilitate the extension of control and authority across space, have an elective affinity with secular forms of governance that are less dependent on the maintenance of continuity over time, and are typically found in societies and cultures prone to social change.

Approaches that, like Innis's, focus on the significance of the medium of communication rather than its content, have been adopted by a range of other authors. Marshall McLuhan, Jack Goody, Ian Watt and Walter Ong, among others, have focused on the shift from oral to written communication, arguing that the introduction of literacy affected social organisation and stimulated the rise of a different mode of consciousness as well as a new conception of the individual (Goody and Watt 1963; McLuhan 1994; Ong 1982). In a related manner, Elizabeth Eisenstein (1979) examined the consequences of print technology, showing its involvement in the growth of modern science, nationalism and the rise of Protestant Reformation.

Existing theories of broadcasting and television, too, tie the distinctive qualities of the medium to its technological characteristics, and examine their affinities with broader social and cultural processes. As even a cursory look at the titles of some of the classic writings in the field attests - from Joshua Meyrowitz's No Sense of Place (1985) and Roger Silverstone's Television and Everyday Life (1994) to Paddy Scannell's Television and the Meaning of Live (2013) television is often seen as a medium defined by its distinct relationship to space and time: its liveness, its ability to cross vast distances in the blink of an eye, and its close association with 
domestic, everyday life. These ways of relating to time and space are, these authors suggest, enabled by the affordances of (classic, pre-digital) broadcast technology, and have an impact on the way individuals and societies relate to space and time.

General discussions of modern means of mass communication likewise pay attention to the affordances of new communication technologies, and typically see them as instrumental in the restructuring of human relationships to time and space, and thereby in fostering the particular temporal and spatial orders characteristic of modern societies (e.g., Morley 2007; Thompson 1995). Most recently, such general arguments about the social consequences of the modern media of communication have been rejuvenated by the fast-growing literature on "mediatization", which likewise seeks to capture the interrelationships between media change on the one hand and social and cultural change on the other (e.g., Couldry and Hepp 2013, Deacon and Stanyer 2015, Hepp et al. 2015, Mazzoleni and Schultz 1999).

This body of work, and especially the writings on television and the modern media, contributes to the analysis developed in this paper. Yet the analysis also departs from this literature in fundamental ways. By and large, writers from Innis and McLuhan, Scannell and Meyrowitz, to Hepp and Couldry tend to foreground the universal characteristics of a particular medium (or modern media in general), and pay limited consideration to how these traits may vary with respect to social and historical context. The only context-dependent variation that does receive substantial recognition is the one arising from audience reception and use; in this sense, for instance, several scholars have shown that the spatial and temporal qualities of communication technologies do not have the capacity to fully determine the social uses of space and time. Instead, the analysis also has to take into account the role of human agency and the ways in which the experience of space in time is formed through media use, a process potentially affected by other, alternative modes of temporality and spatiality. ${ }^{3}$ The framework developed in this paper acknowledges the variations arising from individual media use, but also goes a step further, and offers a framework for analysing how and why the general aspects characteristic of television vary with social, cultural and political context, thereby producing distinct varieties of television culture.

\footnotetext{
${ }^{3}$ For a sample of literature examining the temporality of media use alongside the inherent temporal qualities of communication technologies see Green (2002); Hörning and Gerhard (1999); Keightley (2013); Nansen et al. (2009). A similar shift from the study of the inherent traits of communication technology to the examination of use has occurred in relation to the spatial qualities of the media.
} 
Wordcount: 7995 (references excluded)

\section{Dimensions of Variation}

To develop a comparative framework aligned with the understanding of media and television cultures outlined above, we first need to identify the key dimensions of variation. By way of illustration, the pages that follow discuss four such dimensions, and examine them from the perspective of their relevance to the analysis of television cultures: publicness, privacy, temporal orientation, and secularization. ${ }^{4}$

\section{Publicness: Public Sphere and Public Mission}

The first dimension of variation concerns television's openness to the public realm, which arises from its ability to bring public life into the private lives of millions of citizens. It may be tempting to limit the analysis of television's publicness primarily from the perspective of the public sphere, as theorised by Habermas (1989). In this sense, we can examine the extent to which television enables debate that is independent both from the imperatives of the market and from the encroachments of the state. Yet, as both historical and contemporary debates surrounding public broadcasting remind us, the public remit of television cannot be restricted to its exposure of those in power to public scrutiny. It also encompasses television's capacity to provide access to a range of shared, and hence public, goods: typically, information, education, culture, and entertainment (e.g., Blumler 1992; Bourdon 2011; Tracey 1998). Paddy Scannell's (1996: 165-172) discussion of publicness in relation to broadcasting offers a good example of this duality. On the one hand, he sees publicness as "that which is not concealed, not hidden, not covered up, not covered over ... in short, not secret", but he also contends that publicness is linked to "the availability of things as common, public things". The latter can of course encompass the former: television's ability to make things visible to everyone, and hence open to public scrutiny, can be conceived as a part of its public mission, and hence as one of the public goods it needs to deliver. Nonetheless, in and of itself, television's contribution to visibility and public critique does not exhaust its public remit - which means that television can be seen as in some sense "public" even if it does not fulfil its watchdog role.

To capture the full scope of television's relationship with the public realm, it is therefore important to distinguish between two dimensions of television's publicness: the public sphere and the public mission. Both of these need to be taken into account when developing a

\footnotetext{
${ }^{4}$ This is a very selective list. For a consideration of other dimensions - including gender, extraordinary temporality, and transnationalism - see Anonymised (forthcoming).
} 
Wordcount: 7995 (references excluded)

comparative assessment of TV cultures. With regards to the public sphere, we can differentiate between television cultures depending on the extent to which they enable the public scrutiny of power. In other words, the extent to which they give voice to opinions contrary to, or critical of, those promoted by the ruling elite or official policies, or reveal information that sheds critical light on officially promoted practices or views. Further, more detailed, criteria can be added here, derived from the different normative conceptions of the public sphere beyond the one developed by Habermas (e.g. Ferree et al. 2002; Butler Breese 2011; Downey et al. 2012). It is also important to add that the examination of the public sphere dimension of publicness need not be limited solely to news or current affairs programmes; following the notion of the "cultural public sphere" we can trace different degrees of publicness in educational, entertainment as well as fictional programming (e.g., McGuigan 2005).

With regard to the second dimension of television's publicness, namely public mission, we can compare different television cultures depending on their definition of the medium's public remit. As Jérôme Bourdon (2011: 26-34) argues, the notion of public broadcasting often emerged as a vaguely defined ideal, and even when it was specified more precisely, the exact formulation and the relative emphasis put on different aspects of public mission could vary considerably. To mention but one example: the rationale for public broadcasting in France, as formulated in a document issued in 1964, echoed the trio of functions familiar from British public broadcasting - to inform, to educate, to entertain - but also added a fourth one, culture, and listed it before education and entertainment (Bourdon 2011: 33). This suggests that we can differentiate between television cultures depending on how they articulate their public mission, and specifically depending on the emphasis they put on different public functions. Such a comparison has the potential to bring many surprises to our conventional understanding of the public remit of broadcasting, and highlight surprising similarities between the traditions of public broadcasting that evolved in the West, and those that emerged under totalitarian rule (Anonymized, Forthcoming).

\section{Privacy: Domestication and Privatization}

The second dimension of variation captures television's involvement with the other side of the dichotomy, namely privacy. Arguably, television's connection with privacy is inseparable from its link with the public realm. As noted earlier, television's publicness is predicated on the ability of the medium to bring public life into private lives, a characteristic that also makes physical travel into the outside world unnecessary, thereby enabling TV viewers, as Shaun 
Moores (2000: 96) puts it, to combine "staying at home" and "going places". The hybrid nature of television, as a medium at once private and public, is captured also in Raymond Williams's (2007: 19-22) discussion of "mobile privatization", which was coined to describe a situation in which humans, while living in a world of unprecedented mobility, increasingly function in selfenclosed family units, removed from places of work and government. This particular condition, argued Williams, created a need for new kinds of communication, capable of bringing news or entertainment from otherwise inaccessible sources into private homes - a need fulfilled first by radio, then by television.

As with publicness, two sub-dimensions of television's privacy should be considered. The first of these is domestication, which refers to the extent and modes of adoption of television as a domestic medium, viewed primarily in the context of one's home. The second is privatization, which denotes the extent to which television's programming focuses on private life, mimics intimate modes of communication when addressing the audience, or otherwise becomes adapted to the domestic context of reception. These two sides of television's involvement with the private are tied to what are considered to be some of the key distinguishing features of (analogue) television: on the one hand, the fact that it is intended primarily for viewing in a domestic environment, and hence becomes closely intertwined with domestic and family life, and, on the other hand, its propensity for intimate modes of address, for programmes dedicated to private life, and for genre conventions designed to fit with domestic rhythms (Chambers 2016; Silverstone 1994; Spigel 1992). The viewing context and the aspects of TV form and content are of course closely related: in many respects, the tendency to privacy and intimacy in television programming emerged in direct response to its domestic viewing context. John Corner (2000: 16) called this television's "domestic aesthetic" and argued that television developed an "institutional persona" in which "home-friendly attributes" are key. Of course, many of the "privatized" features of content and form are discernible also in radio programming, but they have arguably become exacerbated in the context of television, due to its visual nature (cf. Meyrowitz 1985: 100).

Television's propensity to be viewed in a domestic setting, its inclination towards narratives of private life, and intimate modes of address do not mean that the medium's engagement with privacy has taken the same form everywhere. Rather, the processes of domestication and privatization of television assumes different shapes depending on the normative, political, economic context. In state socialist countries of Eastern Europe, for instance, privacy held a 
rather uncomfortable position; according to the communist vision of progress, the need for privacy was a by-product of the inequality and alienation generated by capitalism, and hardly something worth protecting (Anonymised 2016). Though official attitudes to privacy changed significantly during the last decades of state socialism, a measure of suspicion persisted, at least in so far as private matters were seen as a threat to citizen investment in public life. It is feasible to expect that television's engagement with privacy reflected these suspicions and that as a consequence, state socialist television cultures were, by and large, less "privatized" and "domesticated" than their counterparts in the West, or at last that privatization and domestication took a different shape, aligned with the pronounced public thrust of the communist project.

\section{Temporal Orientation}

Another dimension worth considering in the comparative study of television cultures concerns temporal orientation, understood as the mode of engagement with the passage of time, and specifically the extent to which a particular television culture is oriented towards the past, present, or future. Television of course has, along with radio, a privileged bond with the present; what distinguishes broadcasting from older media is its ability to make events, programmes and experiences available to dispersed audiences in the blink of an eye, and thereby engender a shared, live connection with the unfolding present. ${ }^{5}$ The wider cultural and social effects of this particular bond with the present, enabled by broadcasting, form part and parcel of a broader reconfiguration that affects not only human engagement with time, but also with space: by virtue of its ability to transmit messages over distance at maximum speed, in fact virtually instantaneously, broadcasting enables people to experience the flow of events and time together, yet without being co-present in the same space. From this point of view, television and radio can be seen as involved in a longer process that has been variously conceptualised in terms of the "speeding up" of time, "time-space compression" and the "separation of time and space", and associated either with (late) modernity or with postmodernity (Giddens 1990; Harvey 1989). This process has been shown to be intimately bound up with successive inventions in modern technologies of communication, and has arguably reached a new stage with the advent of digital and mobile media (Rosa 2013; Thompson 1995: 31-37; Tomlinson 2007: 94-193).

\footnotetext{
${ }^{5}$ This bond with the present, and the associated "liveness" and "dailiness" of broadcasting have been discussed particularly extensively by Paddy Scannell (1996; 2013). Other important discussions on the issue include Bourdon (2000); Ellis (1982, 2000); Marriott (2007).
} 
For several authors, television's live bond with the present effectively renders the medium timeless. In effect, television operates in what Fredric Jameson (1985: 125) has called the "perpetual present," which he associates with "the disappearance of a sense of history", the loss of capacity to retain one's own past, and the obliteration of traditions characteristic of late capitalist postmodernity. ${ }^{6}$ It would be wrong, however, to assume that television's tie with the present eliminates its engagement with the past and the future altogether. Rather, this engagement is folded into the present, and adapted to fit with the medium's present-centred character. Television dramas, films and even reality TV shows often take viewers on a virtual journey into the past, real or imagined, or invite them to imagine the future. Historical serial fiction, in particular, has been shown to exploit the distinct affordances of television, such as its visual nature and the intimate bond with viewers' everyday lives, to encourage a personal, emotionally involved engagement with the past (Creeber 2001). Major festive occasions celebrated through the small screen, including some of the major "media events" that punctuate the broadcast year, serve as reminders of major historical events, and rely for their effectiveness on television's ability to establish a live connection with the passage of time as it unfolds (Dayan and Katz 1992). News broadcasts, too, employ historical analogies as a means of interpreting the present, or incorporate speculations about the future effects of a particular course of events (e.g., Edgerton and Rollins 2001: 230—243, 207-299).

This coexistence of different temporal planes within the same medium also means that despite television's fundamental temporal orientation to the present, television cultures differ in the mode and extent to which they engage with the past and the future, and the level of such engagement over time. Systematic comparative research that investigates such differences and changes is in its infancy, but existing studies suggest that this dimension of variation offers a promising venue for comparative work. For instance, a longitudinal analysis of US print news between 1894 and 1994 showed that the proportion of articles including references to the past or the future, as opposed to the present, increased considerably over time (Barnhurst and Mutz (1997), while another study has shown that print news more often refer to future events, in contrast to online news which are more commonly oriented to recent past events (Tenenboim-Weinblatt and Neiger 2015). A similar approach can be applied to a variety of other media genres, including fiction, and it is also possible to analyse the different articulations of television's temporal orientation across a range of aspects that involve production and reception.

${ }^{6}$ For an example of theorizing that links television's temporality to the perpetual present see Hoskins (2001). 


\section{Secularization}

Another useful dimension of comparison is the degree of secularization, understood here as the extent to which a television culture helps reproduce ideas and practices of religious origin - beliefs in supernatural powers, narratives based on sacred texts, or religious rituals such as prayers and annual religious festivities. The choice of secularization as a key dimension of comparison between television cultures may come as a surprise. The relationship between the media and religion is at best a marginal concern in existing comparative media research, and when it appears, it is bundled together with the discussion of the relationship between media and politics. ${ }^{7}$

Yet as recent research shows, religion continues to have a notable presence in media cultures globally. Even the media in the West are not as devoid of religion as one may think: by and large, mainstream media still observe religious festivities, report on religious developments, and produce religious content, while beliefs in transcendental powers continue to play an important role in popular culture, especially fictional genres. Several authors have examined religious television and the phenomenon of TV evangelism in the United States, as well as the many ways in which religious institutions and audiences have responded to and appropriated modern media technologies for their own purposes (e.g., Abelman and Hoover 1990; Hoover and Schofield Clark 2002; Sa Martino 2013), while others have investigated the persistence of religious themes, narratives and beliefs across different media genres (e.g. Hoover 1998; Knott et al. 2013). The importance of religion for understanding contemporary television and media cultures becomes even more obvious when we broaden our comparative scope beyond the West. In many countries of the Middle East, as well as in Malaysia and parts of Latin America, religion forms a prominent feature of media cultures, including television cultures, and religious institutions often have considerable influence over mass mediated content (e.g. Lewis et al. 2016: 157-195).

The extent of secularization clearly constitutes an important dimension of comparison when looking at television cultures globally. In some cases, modern means of mass communication are successfully mobilized by religious organisations, old and new, to advance their cause; in other cases, they can help diminish the relative influence of institutionalized religion while still

\footnotetext{
${ }^{7}$ Hallin and Mancini (2004: 263-267) talk of secularization in semi-metaphorical terms, as a process that encompasses not only the decline of religious institutions and beliefs, but also the decline of institutions and beliefs tied to ideological "faiths", including political parties and trade unions.
} 
sustaining a degree of diffuse religiosity, spirituality, and observance of religious traditions among the population. Several aspects of television culture can be considered when estimating the extent of secularization. The first, and perhaps most obvious, is the amount of explicitly religious programming, but also the extent to which such programming privileges some forms of religion over others, and either sustains or challenges existing religious beliefs and belonging. The second option involves tracing the more diffuse forms of religion, including references to the sacred, narratives based on sacred texts or beliefs in supernatural forces, across a range of otherwise "secular" genres, from news to fiction, as well as in the context of audience reception. Finally, religion also intervenes in the temporal arrangements of TV broadcasting, in relation to routine daily and weekly scheduling as well as television's involvement in creating a sense of extraordinary, festive occasions.

\section{The Challenges of Methodological Nationalism and Studying Change Over Time}

Apart from practical challenge of collating reasonably comparable empirical materials, comparative research on media cultures has to contend with two challenges of a more general, epistemological nature, namely methodological nationalism and the difficulties of combining cross-country comparison with an account of changes over time. What follows is a brief outline the nature of each of these obstacles, and some suggestions for how to overcome them.

Methodological nationalism, rooted in the assumption that media cultures coincide with national cultures as well as with state borders, constitutes a widespread and problematic aspect of media research. Following this logic, comparative work is often conceived as involving comparisons between national media systems or national media cultures. ${ }^{8}$ By contrast, the framework developed here does not see television cultures as unequivocally "national": even though it recognises that TV cultures are largely tied to particular states and corresponding broadcasting systems, it assumes that they coincide neither with state borders nor with national boundaries. Television was a border-crossing medium from its inception, and even though it was often mobilized for the purpose of state- and nation-building, it simultaneously fostered transnational integration, for instance through organisational and technological infrastructure, through programme exchange, through transnational TV events, through fictional narratives of a shared history, or through cross-border viewing. Indeed, already well before the rise of satellite television, one could find plenty of evidence of 'hybrid'

\footnotetext{
${ }^{8}$ For a critique see Livingstone (2003); Hardy (2012).
} 
Wordcount: 7995 (references excluded)

television cultures tied to multiple states and systems, most obviously in border areas where audiences routinely tuned into broadcasts originating from two or more countries.

The transnational plane can also emerge in the analysis of factors that help explain the diversity of television cultures. The trajectories of television cultures linked to different countries and broadcasting systems are typically closely intertwined, and mutually constitutive. These cross-border entanglements take many forms, ranging from shared histories of infrastructure, cross-border viewing and personnel and programme exchanges to the mimicking of organisational and legal solutions. Failing to attend to these transnational entanglements can give rise to what is known as Galton's problem, namely mistaking the results of transnational borrowing for an outcome of purely domestic factors (Hanitzsch and Esser 2012: 503). To avoid this problem, it is important to pay attention to contextual factors that go beyond the framework of a single state, and consider how particular traits of television cultures may have been shaped by the transnational orientation of a particular broadcasting system, including its incorporation into international broadcast infrastructures and openness to cross-border signals. That said, we should also acknowledge that television cultures are frequently treated by their key actors - policy makers, producers, audiences - as national, and often become more homogeneous as a result of nation-building efforts. Avoiding the challenge of methodological nationalism therefore does not mean denying a measure of national homogeneity altogether; rather, it requires us to avoid assuming that such homogeneity is given, uncontested or permanent, or that it precludes transnational ties and similarities.

The second methodological challenge encountered in the comparative analysis of media cultures arises in cases where comparative analysis is combined with an account of change over time. In the vast majority of existing empirical comparative work in the field, this challenge is absent, as the analysis is typically limited to a short span of time. Yet, if we are to advance the field of comparative media cultures research, the analysis will need to adopt a deeper historical perspective as well. This will mean that the analysis will effectively need to oscillate between cross-country comparison and longitudinal analysis. Such a combination of synchronic and diachronic comparison is not without its challenges. As Winifred Schultz (2014: 66-67) notes in his discussion of longitudinal designs in political communication research, relationships between changing political institutions on the one hand, and changing forms of communication on the other, defy a neat distinction between independent and dependent variables required by standard models of social science research. Apart from complicating a 
neat causal account, the introduction of diachronic comparison can also risk undermining the credibility of synchronous comparisons. As Werner and Zimmermann (2006) argue in their critique of comparative history, delving too deeply into the analysis of historical processes may make it difficult to justify why, in the comparative analysis, one aspect of the historical process is chosen over another.

Nonetheless, the benefits of combining the two planes of analysis are too great to be jettisoned solely on the basis of such obstacles. Quite the contrary: a more complex account of causality, which defies a neat separation of causes and consequences, and challenges attempts to fit the reality of communication into static typologies, are precisely the reasons for why longitudinal comparison should become more widely adopted among communication scholars. Another benefit brought by combining synchronic and diachronic planes of analysis is that this increases the scope of comparison. In addition to comparisons between countries, the longitudinal span opens up opportunities for several within-case comparisons over time, which make it possible to explore the relationship between context and outcome not only by looking at how they co-vary across cases, but also longitudinally. In technical jargon, the addition of historical comparison multiplies the opportunities to test a hypothesis about a causal relationship, and thereby increases the $\mathrm{N}$ within what may initially seem like a single case (Collier 1993: 115).

\section{Conclusions: Towards Comparing Hybrid Media Cultures}

The analytical framework outlined in this paper has been developed primarily with the view of comparing television cultures in the pre-digital era. Nonetheless, the framework has more general applicability. This is most obvious in the case or television's elder broadcast sibling, radio, which in many ways provided a template for the development of television both in terms of its institutional development and with respect to its cultural forms and audience uses. But other media cultures, too - from those associated with film and print publications to those linked to mobile and digital media - can also be analysed and compared along the same dimensions of variation as television.

The current digital and mobile media environment offers a particularly interesting testing ground for the proposed framework. Internet penetration has been increasing rapidly around the world, along with video-on-demand services and the use of screen devices capable of 
transmitting television content, from smart phones to tablets. These changes have certainly dislodged traditional modes of television viewing, and opened up opportunities for consuming television content in a variety of public and private contexts, and at different times. In this sense, as Milly Buonnano (2008: 69) argued, television viewing has become more like reading a book: people can watch it whenever and wherever they want. Yet the extent to which media cultures have changed as a result of these technological changes, or indeed seen a decisive shift from television to other types of digitally mediated content, varies considerably both within and across countries. As Tania Lewis, Frank Martin and Wanning Sun (2016: 3) point out in their study of television in Asia, narratives centred on the West often present television as "a heritage form", but in many countries of South and East Asia the medium remains "the most powerful and ubiquitous media form". Even in the West, television viewing time has continued to increase in the new millennium despite the parallel proliferation of digital and mobile media use (Donders et al. 2016: 51).

It is possible, of course, that the demise of television - and especially traditional television viewing - is only a matter of time, not least because surveys among younger generations frequently highlight their eagerness to embrace new technological developments and abandon traditional television viewing - or even television as such - to a greater extent than older generations. Yet it is still early to ascertain with certainty whether these patterns among youth are an effect of generation or age: will the young "digital natives" or even "mobile natives" of today retain their media habits in the future, as they progress through the life cycle, move into a separate household, or establish a family? There are also clear signs that television is adapting fast, and rather successfully, to the new environment, both by exploiting the new opportunities opened by digital technologies, and by capitalising on its established strengths, including its audio-visual nature and its ability to broadcast events live to large and dispersed audiences. In the realm of television entertainment, content produced by traditional broadcasters still plays an important role, but is often reaching audiences in video-on-demand form, either through catch-up TV services offered by broadcasters themselves or, increasingly so, via subscription-based providers (Lotz 2014; Robinson 2017). In the context of political communication, the televised coverage of elections as well as televised presidential candidate debates retain their position as key reference points in the communicative landscape, even though their significance cannot be understood without attending to the many forms of on-line communication that evolve in parallel through the "second screen" (Vaccari et al. 2015). Increasingly, then, television cannot be confined to the "box in the corner", but operates as a 
"non-site-specific medium" that spreads across a range of devices and platforms from the traditional TV set to mobile phones and tablets (Bennett and Strange 2011).

In this sense, what we are witnessing is perhaps not so much a wholesale transition from television cultures to digital cultures, but rather the rise of a new kind of "hybrid" media cultures, which combine elements of both traditional, analogue broadcasting, and the newer digital and mobile technologies. By analogy with the hybrid media system as theorised by Andy Chadwick (2017), the hybrid media culture arises from the competition and conflict between different media logics, and is characterised patterns of ideas and practice that are informed by both. For instance, while the accessibility of television content via a variety of screens has contributed to a partial "de-domestication" of television viewing, the association between television and the safety and comfort of the home environment seems to persist at least for some viewers (Tsekleves et al. 2011). Likewise, although the temporal arrangements of everyday television viewing have certainly changed as a result of technologies that allow audiences to customise their viewing rhythms depending on their own preferences and schedules, the traditional mode of viewing of broadcast content according to a pre-scheduled flow retains its attractions as well (Gentikow 2010). Another example of hybridisation is provided by the seemingly endless opportunities for re-broadcasting, adaptation and reassembly of television content on-line - a trend reliant on the capacity of the internet to serve as a quasi-archive, with important consequences for the temporal orientation of contemporary media cultures (Ernst 2012; Garde-Hansen et al. 2009). More importantly, even if this hybrid media culture is merely transitory in nature and will eventually give way to a world of more fully fledged digital media cultures in which the notion of television becomes obsolete, the same questions will apply about the embeddedness of new communication devices in everyday life, the provenance of content accessible through them, and ultimately their impact on shared beliefs and practices. The dimensions of comparison introduced in this article should therefore retain their relevance for the comparative analysis of media cultures globally, regardless of technological infrastructure. 


\section{References}

Abelman, Robert, and Stewart M. Hoover, eds. 1990. Religious Television: Controversies and Conclusions, Norwood, NJ: Ablex Publishing.

Allen, Robert C., ed. 1995. To be Continued ... Soap Operas Around the World. London and New York: Routledge.

Anonymised. 2016.

Anonymised. Forthcoming.

Barker, Martin, and Ernest Mathijs. 2008. Watching the Lord of the Rings: Tolkien's World Audiences. New York: Peter Lang.

Barnhurst, Kevin G., and Diana C. Mutz. 1997. "American journalism and the decline on eventcentered reporting." Journal of Communication 47(4): 27-53.

Blumler, Jay. 1992. Television and the Public Interest: Vulnerable Values in Western European Broadcasting, London: Sage.

Blumler, Jay G., and Michael Gurevitch. 1995 [1975]. The Crisis of Public Communication. London and New York: Routledge.

Bourdon, Jérôme. 2000. "Live Television is Still Live: On Television as an Unfulfilled Promise." Media, Culture \& Society 22(5): 531-665.

Bourdon, Jérôme. 2011. Du service public à la télé-réalité: Une histoire culturelle des télévisions européennes, Paris: INA.

Buonnano, Milly. 2008. The Age of Television: Experiences and Theories. Bristol: Intellect.

Butler Breese, Elizabeth. 2011. "Mapping the Variety of Public Spheres." Communication Theory 21(2): 130-149.

Chadwick, Andy. 2017. The Hybrid Media System: Politics and Power, 2nd edn. Oxford: Oxford University Press.

Chalaby, Jean K. 1996. "Journalism as an Anglo-American Invention: A Comparison of the development of French and Anglo-American Journalism, 1830s-1920s." European Journal of Communication 11(3): 303-326.

Chambers, Deborah. 2016. Changing Media, Homes and Households: Culture, Technologies and Meanings. London and New York: Routledge.

Collier, David. 1993. "The Comparative Method." In Ada W. Finifter, Ed., Political science: the state of the discipline II, Washington, DC: American Political Science Association, pp. 105-119.

Couldry, Nick, and Andreas Hepp. 2012. "Comparing Media Cultures." In Frank Esser and Thomas Hanitzsch, Eds. The Handbook of Comparative Communication Research, London and New York: Routledge, pp. 249-261.

Creeber, Glen. 2001. "'Taking our Personal Lives Seriously': Intimacy, Continuity and Memory in the Television Drama Serial", Media, Culture \& Society 23(4): 439-455.

Dayan, Daniel, and Elihu Katz. 1992. Media Events: The Live Broadcasting of History, Cambridge, MA: Harvard University Press.

Deacon, David, and James Stanyer. 2015. "Mediatization: Key Concept or Conceptual Bandwagon?" Media, Culture \& Society 36(7): 1032-1044.

de Vreese, Claes H., Jochen Peter and Holli A. Semetko. 2001. "Framing Politics at the Launch of the Euro: A Cross-National Comparative Study of Frames in the News." Political Communication 18(2): 107-122.

Donders, Karen, Caroline Pauwels and Jan Losen, eds. 2016. Private Television in Western Europe: Contents, Markets, Policies. Basingstoke: Palgrave.

Downey, John, Sabina Mihelj and Thomas König. 2012. "Comparing Public Spheres: Normative Models and Empirical Measurements." European Journal of Communication 27(4): 337-353.

Edgerton, Gary R., and Peter C. Rollins, eds. 2001.Television Histories: Shaping Collective Memory in the Media Age. Lexington: University Press of Kentucky.

Eisenstein, Elizabeth L. 1979. The Printing Press and an Agent of Change: Communications and Cultural Transformations in Early Modern Europe. Cambridge: Cambridge University Press.

Ellis, John. 1982. Visible Fictions: Cinema, Television, Video. London: Routledge. 
Ellis, John. 2002. Seeing Things: Television in the Age of Uncertainty. London and New York: I.B. Tauris.

Ernst, Wolfgang. 2012. Digital Memory and the Archive. Minneapolis, MN: University of Minnesota Press.

Esser, Frank. 1999. "'Tabloidization' of News: A Comparative Analysis of Anglo-American and German Press Journalism." European Journal of Communication 14(3): 291-324.

Esser, Frank. 2013. "The Emerging Paradigm of Comparative Communication Enquiry: Advancing Cross-National Research in Times of Globalization." International Journal of Communication 7: 113-128.

Esser, Frank, and Thomas Hanitzsch, eds. 2012. The Handbook of Comparative Communication Research. London and New York: Routledge.

Ferree, Myra M., William A. Gamson, Jürgen Gerhards, and Dieter Rucht. 2002. "Four Models of the Public Sphere in Modern Democracies." Theory and Society 31(3):289-324.

Furnham, Adrian, and Twiggy Mak. 1999. "Sex-Role Stereotyping in Television Commercials: A Review and Comparison of Fourteen Studies Done on Five Continents Over 25 Years." Sex Roles 41(5): 413-437.

Garde-Hansen, Joanne, Andrew Hoskins and Anna Reading, eds. 2009. Save As ... Digital Memories. Basingstoke: Palgrave.

Gentikow, Barbara. 2010. "Television Use in New Media Environments." In Jostein Gripsrud, ed., Relocating Television: Television in the Digital Context, London and New York: Routledge, pp. 141-155.

Giddens, Anthony. 1990. The Consequences of Modernity, Cambridge: Polity.

Goody, Jack, and Ian Watt. 1963. "The Consequences of Literacy," Comparative Studies in Society and History 5(3): 304-345.

Green, Nicola. 2002. "On the Move: Technology, Mobility, and the Mediation of Social Time and Space", The Information Society 18(4): 281-292.

Gudykunst, William B., and Bella Mody, eds. 2002. Handbook of International and Intercultural Communication. London: Sage.

Habermas, Jürgen. 1989. The Structural Transformation of the Public Sphere: An Inquiry into a Category of Bourgeois Society, translated by Thomas Burger with the assistance of Frederick Lawrence. Cambridge, MA: The MIT Press.

Hallin, Daniel C., and Paolo Mancini. 2004. Comparing Media Systems: Three Models of Media and Politics. Cambridge: Cambridge University Press.

Hallin, Daniel C., and Paolo Mancini, eds. 2012a Comparing Media Systems beyond the Western World. Cambridge: Cambridge University Press.

Hanitzsch, Thomas. 2007. "Deconstructing Journalism Culture: Toward a Universal Theory." Communication Theory 17(4): 367-385.

Hanitzsch, Thomas, and Frank Esser. 2012. "Challenges and Perspectives of Comparative Communication Inquiry." In Frank Esser and Thomas Hanitzsch, eds., The Handbook of Comparative Communication Research, London and New York: Routledge, pp. 501-516.

Hannerz, Ulf. 2004. Foreign News: Exploring the World of Foreign Correspondents. Chicago, IL: University of Chicago Press.

Hardy, Jonathan. 2012. "Comparing Media Systems." In Frank Esser and Thomas Hanitzsch, eds., The Handbook of Comparative Communication Research, London and New York: Routledge, pp. 185-296.

Harvey, David. 1989. The Condition of Postmodernity: An Inquiry into the Origins of Cultural Change, Oxford: Blackwell.

Hepp, Andreas, and Nick Couldry. 2013. "Conceptualizing Mediatization: Contexts, Traditions, Arguments." Communication Theory 23(3): 191-202.

Hepp, Andreas, Stig Hjarvard, and Knut Lundby. 2015. "Mediatization: Theorizing the Interplay between Media, Culture and Society." Media, Culture \& Society 37(2): 314-324.

Hoover, Stewart M. 1998. Religion in the News: Faith and Journalism and American Public Discourse, London: Sage. 
Hoover, Stewart M., and Lynn Schofield Clark. Eds. 2002. Practicing Religion in the Age of the Media, New York, NY: Columbia University Press.

Hörning, Karl H., Daniela Ahrens and Anette Gerhard. 1999. "Do Technologies Have Time? New Practices of Time and the Transformation of Communication Technologies." Time \& Society 8(2): 293-308.

Hoskins, Andrew. 2001. "New Memory: Mediating History." Historical Journal of Film, Radio and Television 21(4): 333-346.

Innis, Harold A. 2007 [1950]. Empire and Communications. Lanham: Rowman \& Littlefield.

Innis, Harold A. 2008 [1951]. The Bias of Communication. Toronto: University of Toronto Press.

Jameson, Frederic. 1985. "Postmodernism and Consumer Society." In Hal Foster, ed., Postmodern Culture, London: Pluto Press, pp. 111-125.

Keightley, Emily. 2013. "From Immediacy to Intermediacy: The Mediation of Lived Time." Time \& Society 22(1): 55-75.

Kellner, Douglas. 1995. Media Culture: Cultural Studies, Identity and Politics between the Modrn and the Postmodern. London and New York: Routledge.

Kim, Young Yun. 2012. "Comparing Intercultural Communication." In Frank Esser and Thomas Hanitzsch, eds., The Handbook of Comparative Communication Research, London and New York: Routledge, pp. 119-133.

Knott, Kim, Elizabeth Poole and Teemu Taira. 2013. Media Portrayals of Religion and the Secular Sacred: Representation and Change. Farnham: Ashgate.

Lewis, Tania, Fran Martin and Wanning Sun. 2016. Telemodernities: Television and Transforming Lives in Asia. Duke University Press.

Liebes, Tamar, and Elihu Katz.1990. The Export of Meaning: Cross-cultural Readings of Dallas, Oxford: Oxford University Press.

Livingstone, Sonia. 2003. "On the Challenges of Cross-National Comparative Media Research." European Journal of Communication 18(4): 477-500.

Livingstone, Sonia. 2012. "Challenges to Comparative Research in a Globalizing Media Landscape." In Frank Esser and Thomas Hanitzsch, eds., The Handbook of Comparative Communication Research, London and New York: Routledge, pp. 415429.

Livingstone, Sonia, and Moira Bovill, eds. 2013. Children and Their Changing Media Environment: A European Comparative Study. Mahwah, NJ: Lawrence Erlbaum.

Lotz, Amanda. 2014. Television Will be Revolutionized, 2nd edn. New York and London: New York University Press.

Marriott, Stephanie. 2007. Live Television: Time, Space and the Broadcast Event. London: Sage.

Mazzoleni, Gianpietro, and Winfried Schultz. 1999. "'Mediatization' of Politics: A Challenge for Democracy? Political Communication 16(3): 247-261.

McGuigan, Jim. 2005. "The Cultural Public Sphere," European Journal of Cultural Studies 8(4): 427-443.

McLuhan, Marshall. 1994 [1964]. Understanding Media: The Extensions of Man. Boston, MA: MIT Press.

Meyrowitz, Joshua. 1985. No Sense of Place: The Impact of Electronic Media on Social Behaviour. Oxford: Oxford University Press,

Moores, Shaun. 2000. Media and Everyday Life. Edinburgh: Edinburgh University Press.

Morley, David. 2007. Media, Modernity and Technology: The Geography of the New. London and New York: Routledge.

Nansen, Bjorn, Michael Arnold, Martin R. Gibbs and Hilary Davis. 2009. "Domestic Orchestration: Rhythms in the Mediated Home." Time \& Society 2/3: 181-207.

Ong, Walter J. 1982. Orality and Literacy: The Technologizing of the Word. New York, NY: Methuen.

Robinson, M. J. 2017. Television on Demand: Curatorial Culture and the Transformation of $T V$. London and New York: Bloomsbury. 
Rosa, Hartmut. 2013. Social Acceleration: A New Theory of Modernity. New York, NY: Columbia University Press.

Sa Martino, Louis Mauro. 2013. The Mediatization of Religion: When Faith Rocks, Farnham: Ashgate.

Scannell, Paddy. 1996. Radio, Television and Modern Life: A Phenomenological Approach, Oxford: Blackwell.

Scannell, Paddy. 2013. Television and the Meaning of Live, Cambridge: Polity.

Schulz, Winfried. 2014. "Political Communication in Long-Term Perspective." In C. Reinemann, ed., Political Communication. Berlin: de Gruyter Mouton, pp 63-85.

Silverstone, Roger. 1994. Television and Everyday Life, London and New York: Routledge.

Spigel, Lynn. 1992. Make Room for TV: Television and the Family Ideal in Post-war America, Chicago, IL: The University of Chicago Press.

Stevenson, Nick. 2002. Understanding Media Cultures: Social Theory and Mass Communication, 2nd edn. London: Sage.

Tenenboim-Weinblatt, Keren, and Motti Neiger. 2015. "Print Is Future, Online Is Past: CrossMedia Analysis of Temporal Orientations in the News." Communication Research 42(8): 1047-1067.

Thompson, John B. 1995. The Media and Modernity: A Social Theory of the Media, Cambridge: Polity Press.

Ting-Toomey, Stella, and Leeva Chung. 2012. Understanding Intercultural Communication, 2nd edn. Oxford: Oxford University Press.

Tomlinson, John. 2007. The Culture of Speed: The Coming of Immediacy, London: Sage.

Tracey, Michael. 1998. The Decline and Fall of Public Broadcasting, Oxford: Oxford University Press.

Tsekleves, Emmanuel, Riger Witham, Koko Kondo and Annette Hill. 2011. "Investigating Media Use and the Television User Experience in the Home." Entertainment Computing 2(3): 151-161.

Vaccari, Cristiano, Andy Chadwick, and Ben O'Loughlin. 2015. "Dual Screening the Political: Media Events, Social Media, and Citizen Engagement." Journal of Communication 65(6): 1041-1061.

van Keulen, Jolien, and Tonny Krijnen. 2014. "The Limitations of Localization: A Cross-Cultural Comparative Study of 'Farmer Wants a Wife'." International Journal of Cultural Studies 17(3): 277-292.

Werner, Michael, and Bénédicte Zimmermann. 2006. "Beyond Comparison: Histoire Croisée and the Challenge of Reflexivity." History and Theory 45(1): 30-50.

Williams, Raymond. 2007 [1974]. Television: Technology and Cultural Form. London and New York: Routledge. 